\title{
Viability of Biofertilizer Produced by an Indian Biodigester Prototype Applied to Sunflower Plants
}

\author{
Luciano Fernandes Moura ${ }^{1,2}$, Pedro Felipe Sousa Teixeira ${ }^{1,2}$, Franklin Aragão Gondim ${ }^{1,2}$, \\ Francisco Holanda Nunes Junior ${ }^{1,2}$, Rifandreo Monteiro Barbosa ${ }^{1}$, Julyanne Fonteles Arruda ${ }^{1}$, Daniel Albiero ${ }^{3}$ \\ \& Auzuir Ripardo Alexandria ${ }^{1,2}$ \\ ${ }^{1}$ Instituto Federal de Educação, Ciência e Tecnologia do Ceará (IFCE), Brazil \\ ${ }^{2}$ Graduate Program in Renewable Energies, Brazil \\ ${ }^{3}$ Centro de Ciências Agrárias, Departamento de Engenharia Agrícola, Universidade Federal do Ceará (UFC), \\ Brazil \\ Correspondence: Auzuir Ripardo Alexandria, Industry Department, Campus Fortaleza, Instituto Federal de \\ Educação, Ciência e Tecnologia do Ceará (IFCE), Graduate Program in Renewable Energies, Brazil. E-mail: \\ auzuir@ifce.edu.br
}

Received: July 12, 2017

Accepted: September 4, 2017 Online Published: September 15, 2017

doi:10.5539/jas.v9n10p253

URL: https://doi.org/10.5539/jas.v9n10p253

\begin{abstract}
Biodigesters have been used to convert biomass into biogas and biofertilizers. This energy use has been important for the reduction of solid waste pollution in the environment. This work aims to analyse the viability of the use of pig biofertilizer produced by an Indian biodigester prototype, monitored by a data acquisition system. The biodigester used was an Indian prototype built on a low cost material that is easy to acquire (polyvinyl chloride-PVC). After the biofertilizer production, we tested its efficiency and viability under conditions of vegetation house in the cultivation of sunflower plants. The experimental design was completely randomized in a factorial arrangement with 4 concentrations of biofertilizer $\left(0,40,80\right.$ and $\left.120 \mathrm{~kg} \mathrm{~N} \mathrm{ha}^{-1}\right) \times 4$ harvest periods $(14,21,25$ and 29 days after sowing). We evaluated biometric and vigor parameters by measurements of stem diameter, height of the aerial part, number of leaves and production of fresh and dry matter of roots, aerial and total parts, as well as the relative chlorophyll content. We performed the experiment with five repetitions using two plants each and we submitted the data to analysis of variance (ANOVA) and polynomial regression using the statistical software Sisvar 5.4. The functional Indian biodigester prototype produced a biofertilizer of excellent quality and viability as a biofertilizer for the initial growth of sunflower plants. The biofertilizer served as a nutritional source in the sunflower crop, since it provided increases in all the growth parameters analyzed in relation to the control group (plants in the absence of biofertilizer), especially in the concentration of $120 \mathrm{~kg} \mathrm{~N}^{-1}$.
\end{abstract}

Keywords: sunflower, bioreactor prototype, biofertilizer, pig

\section{Introduction}

The excessive production of solid waste presents a great challenge to societies, due to its great potential of contamination and degradation of the environment. Waste from the livestock industry causes great environmental degradation when not treated or used correctly (Abdeshahian et al., 2016; Silva et al., 2015). Among the various types of solid waste, animal waste (Biomass) is part of a significant portion of the rejects of agricultural production (Svanberg et al., 2017; Oliver et al., 2008).

According to data from the Agricultural Census (2014) provided by the Brazilian Institute of Geography and Statistics (IBGE), the population of pigs in the country is really high, which is due to the significant growth of the world demand for food. Thus, we evidence the magnitude of the problem and the need for new mechanisms of treatment of their residues. Table 1 presents data on the population of pigs in Brazil, in Ceará and in Maracanaú/CE (Brazil, 2014).

Particularly, when we deal with animal waste, it is worth mentioning that there are areas where animal breeding reaches industrial proportions, which often generates imbalances between vegetables and animal production, and that generates a much larger amount of waste than agricultural production can receive. This can result in 
uncontrolled discharge of waste, thus causing major problems such as contamination of lakes and rivers, infiltration of contaminated water into the water table and development of flies. These are some examples of environmental pollution caused by the various confinement systems of residues (Gebre, 2017; Pohlmann, 2000).

Starting from this problem, the development and implementation of alternative technologies, aiming the generation of energy at reduced costs has been gaining worldwide prominence. According to Al-Masri (2001), the environmental impacts caused by the waste can be minimized by using technologies of energetic reutilization of its nutrients.

Table 1. Population of pigs at national, state and municipal levels

\begin{tabular}{ll}
\hline Location & Number of Animals \\
\hline Brazil & $37,929.357$ Heads \\
Ceará & $1,188,106$ Heads \\
Maracanaú/CE & 3,289 Heads \\
\hline
\end{tabular}

Source: Brazil(2014).

There are several technological alternatives for the use of biomass for energy generation. One of them is the anaerobic biodigestion (AB) of these residues by the implantation of biodigesters (Kamali et al., 2016; Kunz, Higarashi, \& Oliveira, 2005).

$\mathrm{AB}$ emerged in the 1990s in Asia, in the countries of China and India, where the Chineses were looking for the biofertilizer needed to produce food with this technology. The Indians used biodigesters to cover the huge power deficit, which led to the emergence of the two main models: the simpler and more economical Chinese model and the technical and more sophisticated and Indian model to make better use of biogas production (Gaspar, 2003).

According to Coldebella (2004), Sakar, Yetilmezsoy, and Kocak (2009), Sayed et al. (1988), and Amaral et al. (2004), the technology of anaerobic biodigestion is a promising alternative for the treatment of animal waste, because it promotes the generation of biogas, which is used as a source of alternative power, besides reducing the polluting potential and sanitary risks of the waste. It is worth mentioning the important production of biofertilizer, which is the organic matter after undergoing the process of anaerobic digestion, and it is a resource of expressive value, since it can be used in fertilization of crops.

According to Wang et al. (2014), biofertilizer is a co-product obtained from the anaerobic fermentation of crop residues or animal waste in the production of biogas. In general, this product is in liquid form and has a very complex composition of nutrients. Among these, nitrogen and phosphorus stand out, because they are macronutrients essential to plants.

The study of the efficiency of biofertilizers is used as a way to improve specific crops of plants in certain regions, taking into account the climate of the region and agriculture practiced. According to Anguria et al. (2017), the influence of biofertilizers on nutrient absorption and plant quality is not yet fully understood.

Biofertilizers present some advantages when compared to commercial chemical fertilizers: it favors the growth of beneficial microorganisms that provide more health to soil, thus making it more porous, which allows greater aeration in deeper layers. This leads to higher plant growth and development (Izumi et al., 2010), which allows its use in the most diverse plant cultures, including sunflower.

The sunflower (Helianthus annuus L.) is a herbaceous species that originates from North America and belongs to the Asteraceae family (Dall'agnol, et al., 2005). It is an oleaginous that has important agronomic properties, such as resistance to drought, cold and heat greater than most species normally cultivated in Brazil (Leite et al., 2007).

Sunflower is one of the main components of the use of the Brazilian biodiesel program, because it is a plant that produces oil and silage of excellent quality and is widely used for human and animal feed (Ferreira et al., 2011; Porte et al., 2010). However, its major use is mainly as an oleaginous source (Dickmann et al., 2005). Nevertheless, it requires good soil fertility, in order to manifest its characteristics regarding productivity and dry matter.

Other studies with the use of biofertilizers in the development of tours also try to improve the culture as in Braga et al. (2017), with the use of reservoir sediments to grow sunflower plants and Gajdos et al. (2012) to investigate the effects of biofertilizers on plant production and nutrient uptake in some Cd-contaminated soils. 
Studies to improve and optimize the biodigestion process by monitoring the main parameters (Temperature, $\mathrm{pH}$ and Pressure) are very limited, once most biodigesters are located in rural areas difficult to access. Based on this context, a great step to improve and contribute to the consolidation of this technology is to develop a biodigester prototype and an acquisition system with material that is easy to obtain and of low cost, found in local market and that allows the study of the main variables existing during the process at the bench level. In addition, we try to provide an adequate final destination for animal waste, and also the obtaining of good quality biofertilizer.

Therefore, this work aims to analyze the effects of the use of different concentrations of pig biofertilizer produced by an Indian biodigester prototype made of PVC. The biodigester has a data acquisition system, which monitors the source of nutrients in the initial growth of sunflower plants under vegetation house conditions by assessing stem diameter, height of the aerial part, amout of leaves, production of fresh and dry matter of roots and aerial parts and relative contents of chlorophyll. Thus, the hypothesis of this work is that the use of pig biofertilizer in increasing concentrations acts as a fertilizer and causes high growth in sunflower plants.

\section{Materials and Methods}

\subsection{Production and Characterization of the Biofertilizer}

The biofertilizer was produced under anaerobic fermentation for thirty-five days in an Indian biodigester prototype (Figure 1) made of PVC (polyvinyl chloride) tubes, in a screened greenhouse at the Agrometeorological Station, CCA, belonging to the Department of Agricultural Engineering of the Federal University of Ceará-UFC-Pici Campus, located in Fortaleza, Ceará, $\left(3^{\circ} 45^{\prime} \mathrm{S}, 38^{\circ} 33^{\prime} \mathrm{W}\right.$ and altitude of $\left.19 \mathrm{~m}\right)$ Brazil, in September 2016. The mean values of temperature and relative humidity throughout the experiment were $34{ }^{\circ} \mathrm{C}$ and $72 \%$, respectively.

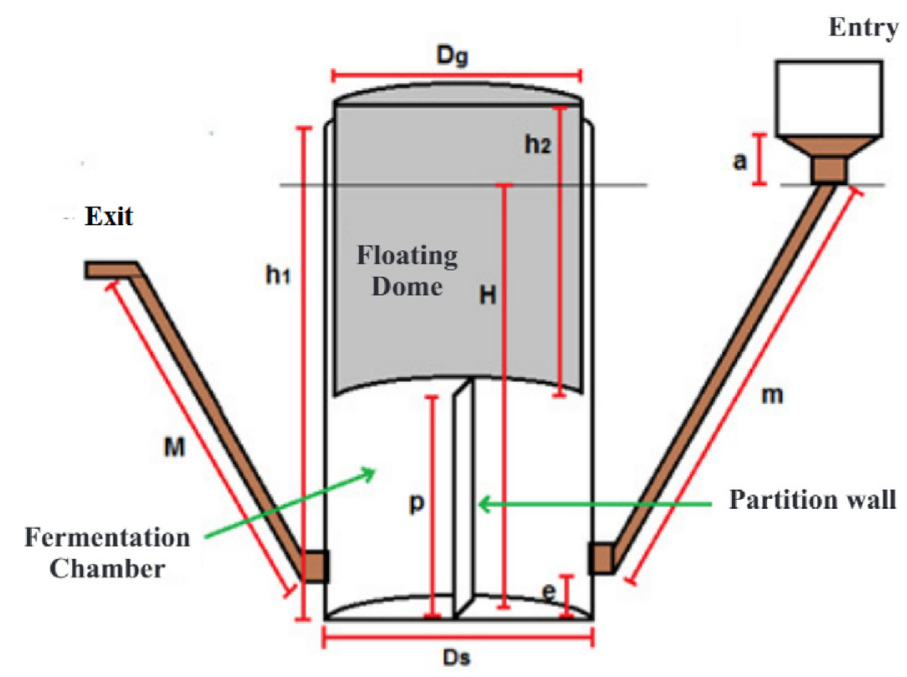

Figure 1. Prototype of Indian biodigester proposed

Note. $\mathrm{H}$ is the height of the substrate level (biomass) $=36 \mathrm{~cm}$; Di is the internal diameter of the biodigester $=150$ $\mathrm{mm}$; Dg is the diameter of the gasometer $=140 \mathrm{~mm}$; Ds is the inside diameter of the top wall $=150 \mathrm{~mm}$; $\mathrm{h} 1 \mathrm{is}$ the idle height (biogas reservoir) $=2 \mathrm{~cm}$; $\mathrm{h} 2$ is the useful height of the gasometer $=20 \mathrm{~cm}$; a is the height of the inlet $=2 \mathrm{~cm}$ (above ground level); $\mathrm{e}$ is the entrance height of the pipe with the affluent $=5 \mathrm{~cm}$; $\mathrm{M}$ is the length of the entrance pipe whose diameter is $32 \mathrm{~mm}=50 \mathrm{~cm}$; $\mathrm{m}$ is the length of the outlet pipe whose diameter is 100 $\mathrm{mm}=20 \mathrm{~cm} ; \mathrm{p}$ is the height of the partition wall $=20 \mathrm{~cm}$.

Source: Adapted from Deganutti et al. (2002).

We chose this Indian model due to its capacity to treat waste as well as the production of biogas. At first, we filled the biodigester with water to verify the occurrence of leaks. Since there was no leak, we collected the fresh swine remains in the experimental area of the Agrometeorological Station. In order to reach the maximum capacity of the reactor, we filled it with $4 \mathrm{~kg}$ of swine waste and $4 \mathrm{~L}$ of water. Before being added into the digestion chamber, the waste underwent a 1:1 (biomass: water) dilution process and was left in batch mode (without daily supply) at an average temperature of $34^{\circ} \mathrm{C}$ without agitation. 
The nutrient concentrations ( $\mathrm{N}, \mathrm{P}, \mathrm{K}, \mathrm{Ca}, \mathrm{Mg}, \mathrm{K}_{2} \mathrm{O}, \mathrm{P}_{2} \mathrm{O}_{5}$ ) of the pig biofertilizer produced in the biodigester are presented in Table 2, using physicochemical analysis carried out at the Soil/Water Laboratory, UFC/FUNCEME. The samples were individually packed in sterile plastic bottles and then transported to the laboratory. We determined the concentration of nitrogen by the Micro Kjedahl method, phosphorus by colorimetry, potassium by flame photometry, and the other nutrients by atomic absorption. All of them were expressed in $\mathrm{g} / \mathrm{L}$, according to the recommendations of (Malavolta, Vitti, \& Oliveira, 1997; Santos, 1991).

Table 2. Physical-chemical characterization of the pig biofertilizer used

\begin{tabular}{|c|c|c|c|c|c|c|c|c|}
\hline \multicolumn{9}{|c|}{ Physical-chemical characterization of the pig biofertilizer } \\
\hline N-t & P-t & $\mathrm{K}^{+}$ & $\mathrm{Ca}^{2+}$ & $\mathrm{Mg}^{2+}$ & $\mathrm{K}_{2} \mathrm{O}$ & $\mathrm{P}_{2} \mathrm{O}_{5}$ & $\mathrm{pH}$ & $\mathrm{EC}$ \\
\hline \multicolumn{9}{|c|}{ 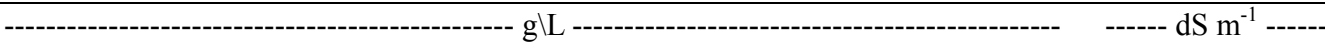 } \\
\hline 3.40 & 0.50 & 0.78 & 1.29 & 0.65 & 0.95 & 1.16 & 7.0 & 10.31 \\
\hline
\end{tabular}

Note. N-t: total nitrogen; P-t: total phosphorus; EC: electric conductivity.

Source: Research data (2017).

\subsection{Experimental Conditions, Vegetal Matter and Treatments}

We conducted the experiment in a vegetation house located in Maracanaú, state of Ceará, Brazil, in November and December 2016. The mean values of temperature and relative humidity in the vegetation house were $26.6{ }^{\circ} \mathrm{C}$ and $65 \%$, respectively.

The sunflower seeds (Helianthus annuus L.), cultivar BRS 323, were provided by Embrapa, Produtos e Mercados-Dourados Office, MS, Brazil. Initially, the seeds were seeded in $5 \mathrm{~L}$ plastic vases, filled with sand of fine granulometry (NBR 6502), after selection and disinfection with $0.7 \%$ sodium hypochlorite.

We conducted four applications of the biofertilizer: at sowing time and 7,14 and 21 days after sowing (DAS). We defined the volumes of biofertilizer applied in each treatment based on the total nitrogen content (N-total) of the sample $(3.40 \mathrm{~g} / \mathrm{L})$ and applied proportionally in the vases corresponding to one hectare under the field conditions in four weekly applications. The applied biofertilizer resulted in treatments containing N-total concentrations of 0 (no application), 40, 80 and $120 \mathrm{~kg} \mathrm{ha}^{-1}$.

\subsection{Collection of Vegetal Matter}

The collection of the vegetal matter was carried out at 14, 21, 25, and 29 DAS. At this time, we separated the plants into roots (29 DAS only) and stalks + petioles + leaves (aerial part) for determination of fresh matter of roots (FMR), fresh matter of aerial part matter (FMAP) and total (FMR + FMAP) by weighing in analytical balance. Then we left the vegetal matter in a greenhouse with forced air circulation at $60^{\circ} \mathrm{C}$, until we obtained constant weight for determination of dry matter of roots (DMR) and dry matter of aerial part (DMAP) in analytical balance.

In each collection, we determined the values of stem diameter(SD) using a digital caliper $(0.01 \mathrm{~mm})$, with measurement performed at the insertion of the epicotyl-hypocotyl axis; The height of the aerial part (HAP) was determined with a ruler graduated in centimeters, measured from the soil surface to the last node and the number of leaves (NF) was manually counted.

We measured the relative chlorophyll contents by using a portable meter-Minolta SPAD-502, Osaka, Japan (using the first fully expanded leaf counting from the apex).

Finally, we submitted all data to analysis of variance (ANOVA) independently and compared the mean values by using regression test through the software Sigma Plot 11.0.

\subsubsection{Experimental Design and Statistical Analysis}

The experimental design was completely randomized in a factorial arrangement with four concentrations of biofertilizer $\left(0,40,80\right.$ and $120 \mathrm{~kg} \mathrm{~N}$ ha $\left.^{-1}\right) \times 4$ collection periods $(14,21,25$, and 29 DAS) and five repetitions with two plants each, which totaled 105 experimental units. We submitted the data to analysis of variance (ANOVA) and polynomial regression by using the statistical software Sisvar 5.4 (Ferreira, 2010).

For technical reasons, the roots were collected only in the last collection (29 DAS), and then used for fresh and dry matter determination of roots and total. Due to this, we submitted the root data to analysis of variance (ANOVA) and compared the mean values by the Tukey's test $(\mathrm{P} \leq 0.05)$ through the software Sigma Plot 11.0. 


\section{Results and Discussions}

By analyzing the data obtained from Anova (Tables 3 and 4), we verified that the use of pig biofertilizer produced in an Indian biodigester prototype as an N-total source in the fertilization of sunflower plants affected significantly $1 \%$ of probability for all the variables analyzed during the study, with interaction between N-total concentrations factors (treatments) and time (days after sowing).

In addition to the 29 DAS, the visual analysis of the seedlings evidence a greater growth in the treatments that received higher concentrations of biofertilizers (Figure 2).

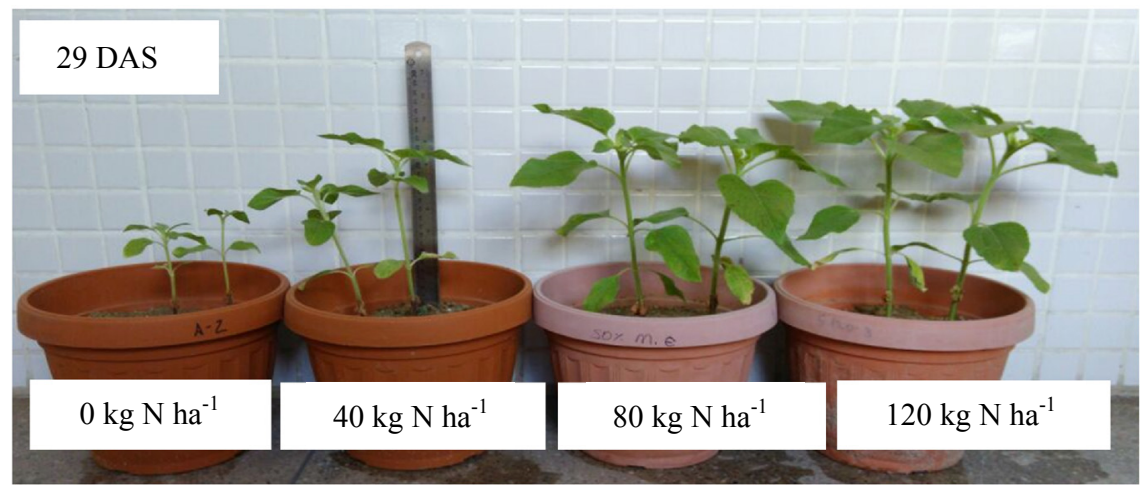

Figure 2. Sunflower seedlings at 29 days after sowing (DAS), growing under different concentrations of pig biofertilizer under vegetation house conditions

Source: Research data (2017).

Relative levels of chlorophyll were higher in treatments with 80 and $120 \mathrm{~kg} \mathrm{~N} \mathrm{ha}^{-1}$ (Figure 3), which are 13.6 and $21 \%$ higher than the control treatment, respectively, at 29 DAS.

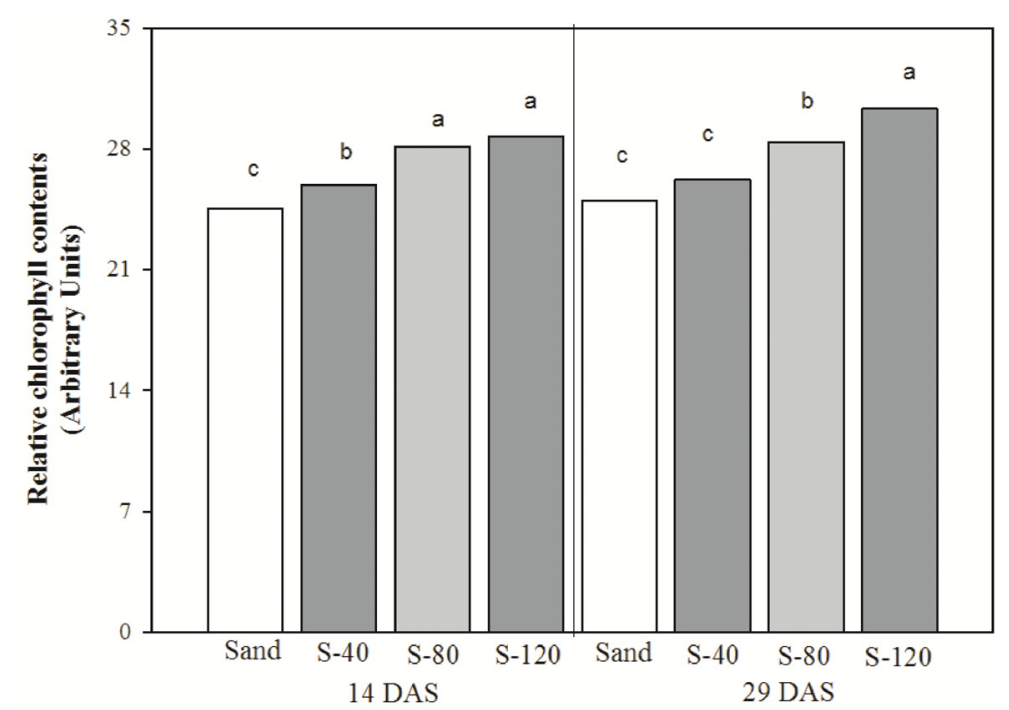

Figure 3. Relative chlorophyll contents at 14 and 29 days after sowing of sunflower seedlings submitted to different concentrations of pig biofertilizer. The bars represent the mean values. Values followed by distinct letters represent statistical differences among the treatments according to Tukey's test $(\mathrm{P} \leq 0.05)$

Source: Research data (2015).

According to Coelho et al. (2010), nitrogen supply is associated with the relative contents in the chlorophyll molecule, because it is present in it. Brighenti (2012) observed that sunflower plants presented, at $30 \mathrm{DAE}$, an 
average ICF value of 35.3. A close value was found in the present work. Thus, the higher availability of $\mathrm{N}$ in increasing concentrations of biofertilizer caused gradual increases in the relative chlorophyll content.

In Figure 4, we can observe the tendencies of sunflower seedlings in the parameters: stem diameter (Figure 4A), height of the aerial part (Figure 4B) and number of leaves (Figure 4C) over time.

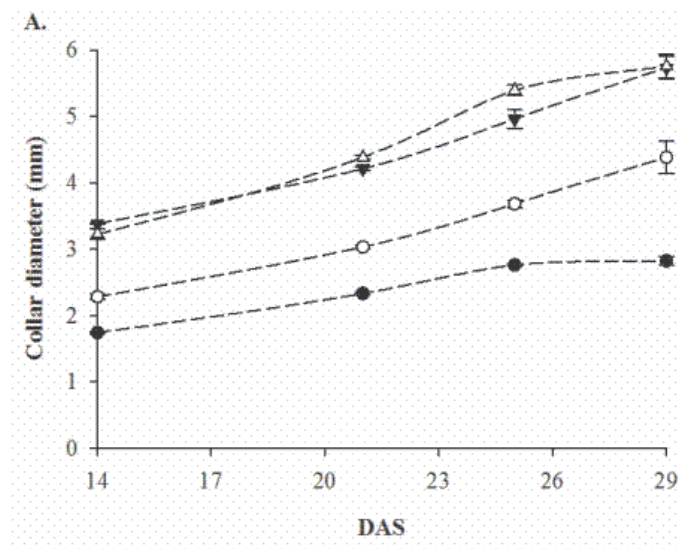

- $0 \mathrm{~kg} \mathrm{~N}-\mathrm{y}=0.367^{\circ} \mathrm{x}+1.495^{\circ *}, \mathrm{R}^{2}=0.9029$

○ $40 \mathrm{~kg} \mathrm{~N}-\mathrm{y}=0.695 * \mathrm{x}+1.605^{\mathrm{n}}, \mathrm{R}^{2}=0.9993$

$80 \mathrm{~kg} \mathrm{~N}-\mathrm{y}=0.78^{*} \mathrm{x}+2.62^{*}, \mathrm{R}^{2}=0.9995$

$\triangle 120 \mathrm{~kg} \mathrm{~N}-\mathrm{y}=0.86^{*} \mathrm{x}+2.535^{*}, \mathrm{R}^{2}=0.9554$
B.

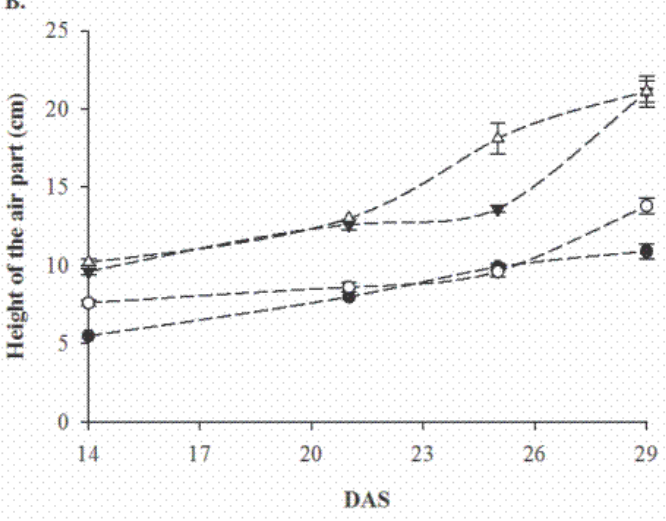

- $0 \mathrm{~kg} \mathrm{~N}-\mathrm{y}=1.81^{*} \mathrm{x}+4.05^{\mathrm{ns}}, \mathrm{R}^{2}=0.9665$ $0.40 \mathrm{~kg} \mathrm{~N}-\mathrm{y}=0.8^{*} \mathrm{x}^{2}-2.04^{* *} \mathrm{x}+9^{*}, \mathrm{R}^{2}=0.977$

> $80 \mathrm{~kg} \mathrm{~N}-\mathrm{y}=1.4167 * \mathrm{x}^{3}-9.5 * \mathrm{x}^{2}+21.583 * \mathrm{x}-3.9 *, \mathrm{R}^{2}=1$

$\triangle 120 \mathrm{~kg} \mathrm{~N}-\mathrm{y}=0.05^{* * \mathrm{x}^{2}}+3.53^{\text {ss }} \mathrm{x}+6.4^{\mathrm{ns}}, \mathrm{R}^{2}=0.9866$

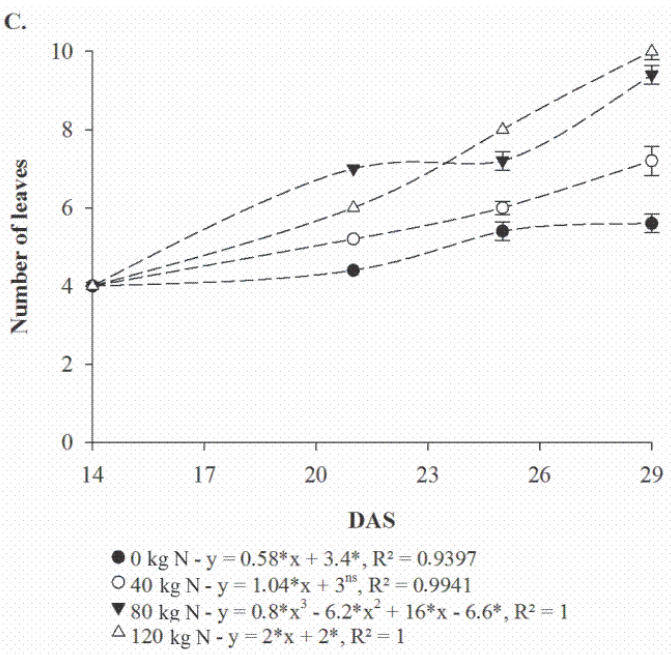

Figure 4. Stem diameter (A), height of the aerial part (B) and number of leaves (C) of sunflower seedlings submitted to different concentrations of pig biofertilizer as source of $\mathrm{N}$-total in different collection periods in days after sowing (DAS). Values represent the means of 5 replicates \pm standard errors

Source: Research data (2017).

In general, the treatment that contains $120 \mathrm{~kg} \mathrm{~N} \mathrm{ha}^{-1}$ was the one that promoted the greatest increases in the analyzed variables, although it does not seem to differ from the $80 \mathrm{~kg} \mathrm{~N} \mathrm{ha}^{-1}$ one. The $120 \mathrm{~kg} \mathrm{~N}^{-1}$ treatment equations were adjusted to the linear models for stem diameter and number of leaves (Figures $4 \mathrm{~B}$ and $4 \mathrm{C}$ ) and quadratic for the height of the aerial part (Figure 4B). 
Table 3. Summaries of variance analyzes for number of leaves (NL), stem diameter (SD), height of the aerial part (HAP) of sunflower plants submitted to different concentrations of pig biofertilizer as source of N-total over time

\begin{tabular}{lllll}
\hline \multirow{2}{*}{ Variation Factor } & DF & \multicolumn{3}{c}{ Mean Square } \\
\cline { 3 - 5 } & & $\mathrm{NL}$ & $\mathrm{SD}$ & HAP \\
\hline Treatment & 3 & $21.74^{*}$ & $22.37^{*}$ & $222.62^{*}$ \\
Time & 3 & $58.11^{*}$ & $25.26^{*}$ & $263.53^{*}$ \\
Treatment vs Time & 9 & $3.95^{*}$ & $0.47^{*}$ & $13.95^{*}$ \\
Error & 64 & 0.17 & 0.05 & 1.05 \\
Total Corrected & 79 & - & - & - \\
CV $(\%)$ & - & 6.8 & 6.2 & 8.4 \\
\hline
\end{tabular}

Note. * Significant at 0.01 by the test F, DF: degree of freedom; CV: coefficient of variation.

Source: Research data (2017).

Table 4. Summaries of variance analysis for fresh matter of the aerial part (FMAP) and dry matter of the aerial part (DMAP) of sunflower plants submitted to different concentrations of pig biofertilizer as source of N-total over time

\begin{tabular}{llll}
\hline \multirow{2}{*}{ Variation Factor } & \multirow{2}{*}{ DF } & \multicolumn{2}{c}{ Mean Square } \\
\cline { 3 - 4 } & & FMAP & DMAP \\
\hline Treatment & 3 & $184.08^{*}$ & $2.04^{*}$ \\
Time & 2 & $177.84^{*}$ & $1.86^{*}$ \\
Treatment vs Time & 6 & $36.04^{*}$ & $0.27^{*}$ \\
Error & 48 & 0.05 & 0.00 \\
Total Corrected & 59 & - & - \\
CV $(\%)$ & - & 5.6 & 9.4 \\
\hline
\end{tabular}

Note. * Significant at 0.01 by the test F, GL: degree of freedom and CV: coefficient of variation.

Source: Research data (2017).

Additionally, we observed increases in 40,80 and $120 \mathrm{~kg} \mathrm{~N} \mathrm{ha}^{-1}$ treatments when compared to the control group for all the collection periods. However, the greatest differences occurred at 29 DAS. In general, the highest values were found in plants that received $120 \mathrm{~kg} \mathrm{~N} \mathrm{ha}^{-1}$. At $29 \mathrm{DAS}$, the $120 \mathrm{~kg} \mathrm{~N} \mathrm{ha}^{-1}$ treatment was superior to the control in 104, 93.5 and $78.5 \%$ for the variables stem diameter (Figure 4A), height of the aerial part (Figure 4B) and number of leaves (Figure 4C), respectively.

According to Silva et al. (2010), $\mathrm{N}$ is one of the main macronutrients associated with plant growth, and low concentrations directly affect the number of leaves, leaf area, stem diameter and height. In general, the analysis of the parameters: stem diameter (Figure 4A), height of the aerial part (Figure 4B) and number of leaves (Figure 4C) demonstrated that the application of pig biofertilizer to the growth environment, mainly to $120 \mathrm{~kg} \mathrm{of}^{\mathrm{N} \text { ha }}{ }^{-1}$, promoted some increase when compared to the control treatment. Regarding the results previously mentioned, we can highlight the increase in number of leaves, due to their importance in the photosynthetic process, especially when associated to the increase of the leaf area (Karadogan \& Akgün, 2009). In addition, it is possible that the increase in the relative contents of chlorophyll (Figure 3) caused by the increasing concentrations of biofertilizer have contributed to a greater photosynthetic capacity, and therefore to the increase in the analyzed variables.

In general, FMAP (Figure 5A), DMAP (Figure 5B), the treatments of 80 and mainly the one of $120 \mathrm{~kg} \mathrm{~N} \mathrm{ha}^{-1}$ were the ones that obtained the largest accumulations of matter at the end of the collection period in relation to the control treatment. Both FMAP and DMAP were adjusted to the response curves with quadratic equations and adjustment coefficients $R^{2}=1$. 

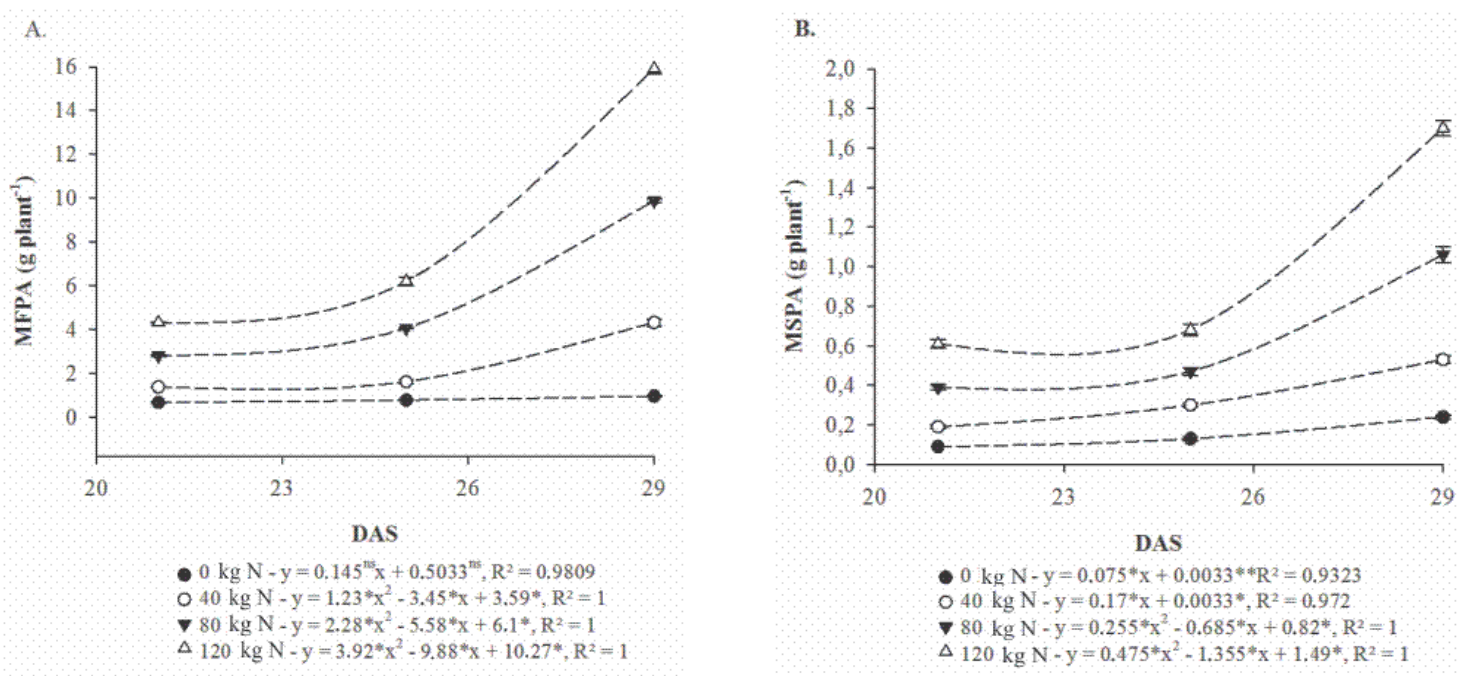

Figure 5. Fresh matter of the aerial part (FMAP) and dry matter of the aerial part (DMAP) of sunflower seedlings submitted to different concentrations of pig biofertilizer as source of $\mathrm{N}$-total in different collection periods in days after sowing (DAS ). Values represent the means of 5 replicates \pm standard errors

Source: Research data (2017).

The results for DMAP are similar to those found by Figueredo (2012), who observed an increase in the DMAP due to the increase of the doses of biofertilizers in the agronomic performance of peanut.

The treatment of $120 \mathrm{~kg} \mathrm{~N} \mathrm{ha}^{-1}$ was the one that obtained the highest values at the end of the collection period (29 DAS), which was respectively 620 and $533 \%$ higher than the control treatment in the fresh matter of roots (FMR) and dry matter of roots (DMR) variables (Figure 6).

A.

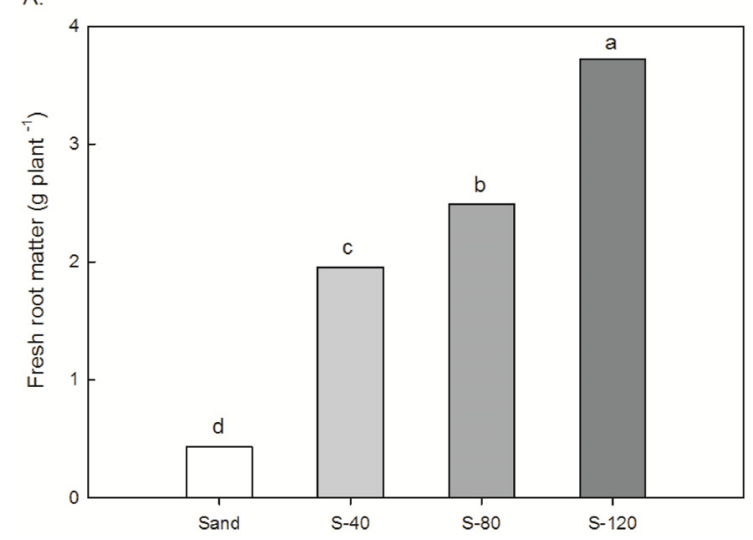

B.

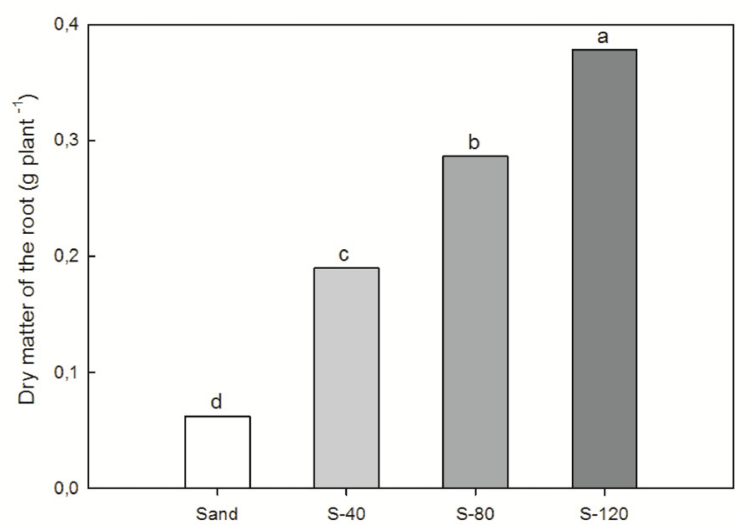

Figure 6. Fresh (A) and dry (B) matter of roots of sunflower seedlings submitted to different concentrations of pig biofertilizer as source of $\mathrm{N}$-total at $29 \mathrm{DAS}$ after sowing. The bars represent the mean values of 5 repetitions. Values followed by distinct letters represent statistical differences among the treatments according to Tukey's test $(\mathrm{P} \leq 0.05)$

Source: Research data (2017).

For the production of total fresh matters (TFM) and total dry matters (TDM) (Figure 7), the values obtained showed higher increases in the treatments with higher biofertilizer concentrations, especially the plants that received 80 and $120 \mathrm{~kg} \mathrm{~N} \mathrm{ha}^{-1}$. At the end of the analysis period (29 DAS), the differences of 80 and $120 \mathrm{~kg} \mathrm{~N}$ 
$\mathrm{ha}^{-1}$ treatments compared to the control (absence of biofertilizer) were 850 and $900 \%$ for TFM and 316 and $568 \%$ for TDM respectively.

A.

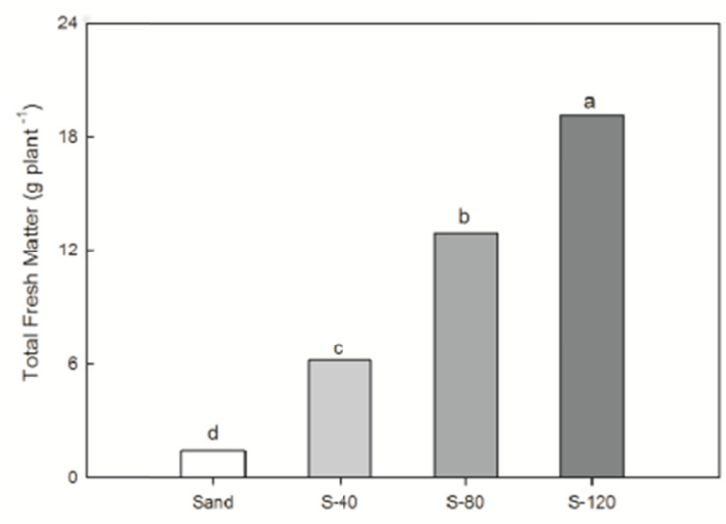

B.

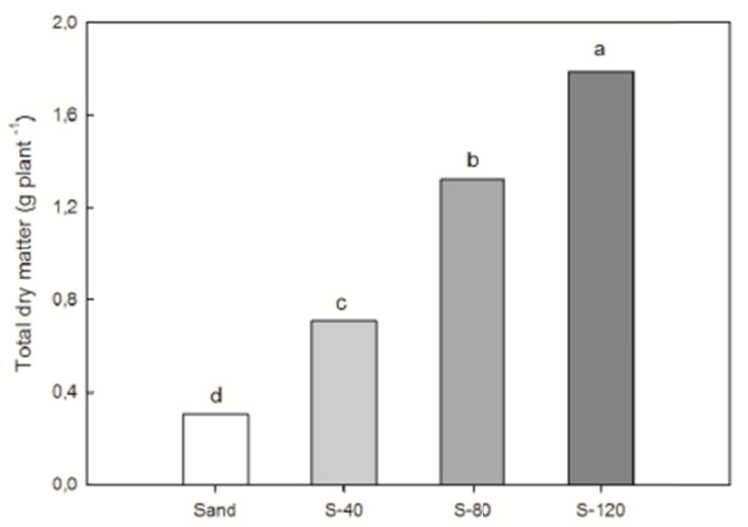

Figure 7. Total fresh (A) and dry (B) matter at 29 days after sowing of sunflower seedlings submitted to different concentrations of pig biofertilizer. The bars represent the mean values of 5 repetitions. Values followed by distinct letters represent statistical differences among the treatments according to Tukey's test $(\mathrm{P} \leq 0.05)$

Source: Research data (2017).

The results found for these variables were similar to those described by Barboza et al. (2010) in experiments using sewage sludge as a source of nutrients in the cultivation of bean plants. The authors observed increases in the dry matter of the aerial part and roots in relation to the control $\left(0 \mathrm{mg} \mathrm{ha}^{-1}\right)$ at higher concentrations $(75 \mathrm{mg}$ $\mathrm{ha}^{-1}$ ) of the residue.

In the present work, we demonstrate the viability of the use of pig biofertilizer in plant cultivation. Thus, this may be an alternative, due to the growing demand for food with less use of synthetic fertilizers and agrochemicals. Additionally, some authors believe in the reduction of the risks of contamination to humans with the use of organic products, reduction in contamination levels of soil, water, plant and living components of agroecosystems (Diniz et al., 2011). According to Tesseroli Neto (2006), liquid biofertilizers can be used in many contexts, either as a single source of nutrients or associated with mineral fertilizers, and they bring on beneficial effects to the chemical, physical and biological characteristics of the soil.

Similarly to the present study, other studies have also demonstrated the efficiency of the use of biofertilizer in fertilization. However, there are no reports in the literature on the use of increasing concentrations of biofertilizer produced in an Indian biodigester prototype in sunflower cultivation.

Dias et al. (2011) observed an increase in passion fruit productivity due to the raise in the frequency of biofertilizer application. Chiconato et al. (2013) observed that the highest biofertilizer dose $\left(60 \mathrm{~m}^{3} \mathrm{ha}^{-1}\right)$ was responsible for the greater development of crop in studies with lettuce cultivation. However, excessive nutrients can cause stabilization and crop yield decline, as found by Oliveira et al. (2001) in cowpea beans.

The use of residues in agricultural activity is interesting from the economic point of view since it provides increased productivity of the plants and reduces the cost with fertilizers, besides providing the safe deposition of these materials in the environment (Figueiredo \& Tanamati, 2010).

Although there is no specific legislation in Brazil for the use of waste in agriculture (Rossol et al., 2012), this problem is inserted in the current context of the national solid waste policy, based on the law number $12.305 / 2010$, which establishes the national solid waste policy and deals with the protection of public health and environmental quality, the non-generation, reduction, reuse, recycling and treatment of solid wastes, as well as environmentally appropriate disposal of tailings and still stimulates the adoption of sustainable patterns of production and consumption of goods and services.

Sunflower cultivation has a minimum and maximum fertilization ranging from 40 to $80 \mathrm{~kg} \mathrm{~N}^{-1}$ (Lobo et al., 2011) in its culture indications. However, we found higher values in the variables analyzed in the treatment of 
$120 \mathrm{~kg} \mathrm{~N} \mathrm{ha}^{-1}$ in the present study. Therefore, we suggest that the application of high concentrations of biofertilizer as a nutritional source is definitely possible.

\section{Conclusion}

The different concentrations of swine biofertilizer produced in an Indian biodigester prototype constructed of $\mathrm{PVC}$ used in sunflower seedlings promoted increases in all variables analyzed in relation to the control (absence of fertilizer), especially in the treatment of $120 \mathrm{~kg} \mathrm{~N} \mathrm{ha}^{-1}$.

In the experimental conditions used, the use of this substrate as organic fertilizer in the cultivation of sunflower plants proved to be feasible.

We believe that the cost may be lower when compared to commercial fertilizers, since it can be easily produced by anaerobic or aerobic fermentation process of the waste in biodigesters. In addition, the production of biofertilizer is an alternative for the destination of the swine residue.

New directions for this work are: to study new fractions of mixtures for biomass of swine and cattle, through the characterization of the initial biomass; To produce new biofertilizers by means of anaerobic biodigestion of other residues, testing on the sunflower crop for growth analysis; Apply the biofertilizer produced in other crops, such as: corn, wheat, castor bean and check the yield of the crops at the end.

\section{Acknowledgements}

The authors would like to thank Capes, CNPq, IFCE, UFC and Funcap for finantial support.

\section{References}

Abdeshahian, P., Lim, J. S., Ho, W. S., Hashim, H., \& Lee, C. T. (2016). Potential of biogas production from farm animal waste in Malaysia. Renewable and Sustainable Energy Reviews, 60, 714-723. https://doi.org/10.1016/j.rser.2016.01.117

Al-Masri, M. R. (2001). Changes in biogas production due to different ratios of some animal and agricultural wastes. Bioresource Technology, 77(1), 97-100. https://doi.org/10.1016/S0960-8524(00)00117-6

Amaral, C. M. C., Amaral, L. A., Júnior, J. L., Nascimento, A. A., Ferreira, D. S., \& Machado, M. R. F. (2004). Biodigestão anaeróbia de dejetos de bovinos leiteiros submetidos a diferentes tempos de retenção hidráulica. Revista Ciência Rural, 34(6), 1897-1902. https://doi.org/10.1590/S0103-84782004000600035

Anguria, P., Chemining'wa, G., Onwonga, R., \& Ugen, M. (2017). Effect of Organic Manures on Nutrient Uptake and Seed Quality of Sesame. Journal of Agricultural Science, 9(7), 135. https://doi.org/10.5539/ jas.v9n7p135

Barboza, R. S. L., Messias, A. S., Figueiredo, M. V. B., \& Lima, V. N., \& Reis, O. V. (2010). Evaluation of potential sewage usage associated to the strain inoculation from Bradyrhizobium spp. in cowpea. Global Journal of Management and Business Research, 10(3), 61-68. https://globaljournals.org/GJMBR Volume10/gjmbr_vol10_issue3_8.pdf

Braga, B., Junior, F., Barbosa, R., Brito, P., Martins, K., Medeiros, P., \& Gondim, F. (2017). Biomass Production and Antioxidative Enzyme Activities of Sunflower Plants Growing in Substrates Containing Sediment from a Tropical Reservoir. Journal of Agricultural Science, 9(5), 95. https://doi.org/10.5539/jas.v9n5p95

Brazil. (2010). Constituição Federal do Brazil. Lei no. 12.305. Retrieved from http://www.planalto.gov.br/ ccivil_03/constituicao/constituicao.htm

Brazil. (2014). Instituto Brasileiro de geografia e estatística. Indicadores IBGE/IPARDES-Censo Agropecuário 2014. Brasília, DF. Retrieved from https://www.ibge.gov.br/home/estatistica/economia/forum_questionario_ censoagro2015/2_Forum_Censo_Agropecuario_2015.pdf

Brighenti, A. M. (2012). Resistência do girassol a herbicidas inibidores da enzima acetolactato sintase. Pesquisa Agropecuária Tropical, 42(2), 225-230. https://doi.org/10.1590/S1983-40632012000200014

Chiconato, D. A., de Simoni, F., Galbiatti, J. A., Franco, C. F., \& Caramelo, A. D. (2013). Resposta da alface à aplicação de biofertilizante sob dois níveis de irrigação. Biosci. J., 29(2), 392-399. Retrieved from http://www.seer.ufu.br/index.php/biosciencejournal/article/view/14077

Coelho, F. S., Fontes, P. C. R., Puiatti, M., Neves, J. C. L., \& Silva, M. C. De C. (2010). Doses de nitrogênio associado à produtividade de batata e índice do estado de nitrogênio na folha. Revista Brasileira de Ciência do Solo, 34(4), 1175-1183. https://doi.org/10.1590/S0100-06832010000400017 
Coldebella, A. (2004). Viabilidade da cogeração de energia elétrica com biogás da bovinocultura de leite (Dissertação, Mestrado em engenharia Agrícola, Universidade Estadual do Oeste do Paraná, UNIOESTE, Cascavel, PR). Retrieved from https://www.journalofbusiness.org/index.php/GJMBR/article/view/152

Dall'agnol, A., Vieira, O. V., \& Leite, R. M. V. B. C. (2005). Origem E Histórico Do Girassol. In R. M. V. B. C. Leite, A. M. Brighenti, \& C. Castro (Eds.), Girassol no Brasil (pp. 1-14). Londrina: Embrapa Soja.

Deganutti, R., Palhaci, M. C. J. P., Rossi, M., Tavares, R., \& Santos, C. (2002). Biodigestores rurais: Modelo indiano, chinês e batelada. Encontro de Energia no Meio Rural. Bauru, SP: SciELO Brazil. Retrieved from http://www.proceedings.scielo.br/scielo.php?pid=MSC0000000022002000100031\&script=sci_arttext\&tlng $=\mathrm{pt}$

Dias, T. J., et al. (2011). Produção do maracujazeiro e resistência mecânica do solo com biofertilizante sob irrigação com águas salinas. Ciências Agronômica. https://doi.org/10.1590/S1806-66902011000300010

Dickmann, L., Carvalho, M. C., Braga, L. F., \& Sousa, M. P. (2005). Comportamento de sementes de girassol (Helianthus annuus L.) submetidas a estresse salino. Revista de Ciências Agro-Ambientais, 3, 64-75. Retrieved from http://www.unemat.br/revistas/rcaa/docs/vol3/6_artigo_v3.pdf

Diniz, A. A., et al. (2011). Esterco líquido bovino e ureia no crescimento e produção de biomassa do maracujazeiro amarelo. Revista Ciência Agronômica, 42(3), 597-604. https://doi.org/10.1590/ S1806-66902011000300004

Embrapa (Empresa Brazileira de Pesquisa Agropecuária). (2002). Resultado de pesquisa da EMBRAPA Soja-2001: girassol e trigo (Documento no. 199, p. 21). Londrina: EMBRAPA Soja.

Ferreira, D. F. S. (2010). Sistema de análise de variância (Versão 5.4). Lavras: UFLA.

Ferreira, T. C., Souza, J. T. A., Araújo, E. C. L., Silva, K. E., Pereira, C. G., \& Oliveira, S. J. C. (2011). Acúmulo de fitomassa seca em girassol (Helianthus annus L.) fertirrigado com urina de vaca e manipueira. Cadernos de Agroecologia, 6(2), 1-5.

Figueiredo, P. G., \& Tanamati, F. Y. (2010). Adubação orgânica e contaminação ambiental. Revista Verde de Agroecologia e Desenvolvimento Sustentável, 5, 1-4. Retrieved from http://diretorio.rcaap.pt/handle/1/544

Figueredo, L. F. de. (2012). Desempenho agronômico do amendoim cv. BR1 submetido a fontes e doses de biofertilizante (Dissertação, Mestrado em Ciências Agrárias, Centro de Ciências Humanas e Agrárias, Universidade Estadual da Paraíba).

Gajdos, É., Lévai, L., Veres, S., \& Kovács, B. (2012). Effects of biofertilizers on maize and sunflower seedlings under cadmium stress. Communications in Soil Science and Plant Analysis, 43(1-2), 272-279. https://doi.org/10.1080/00103624.2011.638591

Gebre, A. E. (2017). Assessment of Assela Town municipality waste water discharge effect on the chemical and bacteriological water pollution load of Anko River. International Journal of Water Resources and Environmental Engineering, 9(7), 142-149. https://doi.org/10.5897/IJWREE2016.0701

Izumi, K., Okishio, Y., Nagao, N., Niwa, C., Yamamoto, S., \& Toda, T. (2010). Effects of particle size on anaerobic digestion of food waste. International Biodeterioration \& Biodegradation, 64(7), 601-608. https://doi.org/10.1016/j.ibiod.2010.06.013

Kamali, M., Gameiro, T., Costa, M. E. V., \& Capela, I. (2016). Anaerobic digestion of pulp and paper mill wastes-An overview of the developments and improvement opportunities. Chemical Engineering Journal, 298, 162-182. https://doi.org/10.1016/j.cej.2016.03.119

Karadogan, T., \& Akgün, Í. (2009). Effect of leaf removal on sunflower yield and yield components and some quality characters. Helia, 32, 123-134. https://doi.org/10.2298/hel0950123k

Kunz, A., Higarashi, M. M., \& Oliveira, P. A. (2005). Tecnologias de manejo e tratamento de dejetos de suínos estudadas no Brazil. Embrapa: Cadernos de Ciência \& Tecnologia, 22(1), 651-665. Retrieved from http://seer.sct.embrapa.br/index.php/cct/article/view/8663

Leite, R. M. V. B. C., Castro, C., Brighenti, A. M., Oliveira, F. A. de, Carvalho, C. G. P., \& Oliveira, A. C. B. (2007). Indicações para o cultivo de girassol nos Estados do Rio Grande do Sul, Paraná, Mato Grosso do Sul, Mato Grosso, Goiás e Roraima. Londrina: Embrapa Soja. Retrieved from http://www.almanaquedocampo.com.br/imagens/files/indica\%C3\%A7\%C3\%B5es\%20girassol.pdf 
Lira, M. A., Chagas, M. C. M., Bristot, G., Dantas, J. A., Holanda, J. S., \& Lima, J. M. P. (2007). In R. N. Natal (Ed.), Recomendações técnicas para o cultivo do girassol. EMPARN.

Lobo, T. F., Grassi Filho, H., \& Britto, I. C. A. (2011). Efeito do nitrogênio na nutrição do girassol. Biosci. J. Uberlândia, 27, 380-391. Retrieved from http://hdl.handle.net/11449/6274

Malavolta, E. (1970). ABC da adubação (5th ed.). São Paulo: Agronômica Ceres.

Malavolta, E., Vitti, G. C., \& Oliveira, S. A. (1997). Avaliaçao do estado nutricional das plantas, princípios e aplicaçoes (2nd ed.). Piracicaba: Potafos.

Oliveira, A. P., et al. (2001). Rendimento de feijão-caupi cultivado com esterco bovino e adubo mineral. Horticultura Brazileira, 19. https://doi.org/10.1590/S0102-05362001000100017

Pohlmann, M. (2000). Levantamento de técnicas de manejo de resíduos da bovinocultura leiteira no estado de São Paulo (Dissertação, Mestrado, Faculdade de Engenharia Agrícola da Universidade Estadual de Campinas, Campinas). Retrieved from http://unicamp.sibi.usp.br/handle/SBURI/82842

Porte, A. F., de Souza Schneider, R. D. C., Kaercher, J. A., Klamt, R. A., Schmatz, W. L., Da Silva, W. L. T., \& Severo Filho, W. A. (2010). Sunflower biodiesel production and application in family farms in Brazil. Fuel, 89(12), 3718-3724. https://doi.org/10.1016/j.fuel.2010.07.025

Rossol, C. D., Filho, H. S., Berté, L. N., Jandrey, P. E., Schwantes, D., \& Gonçalves Junior, A. C. (2012). Caracterização, classificação e destinação de resíduos da agricultura. Scientia Agraria Paranaensis, 11, 33-43. https://doi.org/10.1818/sap.v11i4.5858

Sakar, S., Yetilmezsoy, K., \& Kocak, E. (2009). Anaerobic digestion technology in poultry and livestock waste treatment: A literature review. Waste Management \& Research, SAGE Publications, 27(1), 3-18. https://doi.org/10.1177/0734242X07079060

Santos, A. C. V. D. (1991). Efeitos nutricionais e fitossanitários do biofertilizante líquido a nível de campo. Revista Brazileira de Fruticultura, 13(4), 275-279.

Sayed, S., Zanden, V. D. J., Wijffels, R., \& Lettinga, G. (1988). Anaerobic degradation of the various fractions of slaughterhouse wastewater. Biological Wastes, 23(2), 117-142. https://doi.org/10.1016/0269-7483(88) 90069-9

Silva, F. F. M. Da., Bertini, L. M., Alves, L. A., Barbosa, P. T., Moura, L. F., \& Macêdo, C. S. (2015). Implicações e possibilidades para o ensino a partir da construção de biodigestor no IFRN-campus Apodi. HOLOS, 6, 315-327. https://doi.org/10.15628/holos.2015.3091

Silva, P. C. C., Couto, J. L. Do, \& Santos, A. R. dos. (2010). Efeitos dos íons amônio e nitrato no desenvolvimento do girassol em solução nutritiva. Revista FZVA, 17, 104-114. Retrieved from $\mathrm{http} / / /$ revistaseletronicas.pucrs.br/ojs/index.php/fzva/article/view/7140/0

Svanberg, M., Finnsgård, C., Flodén, J., \& Lundgren, J. (2017). Analyzing animal waste-to-energy supply chains: The case of horse manure. Renewable Energy. https://doi.org/10.1016/j.renene.2017.04.002

Tesseroli Neto, E. A. (2006). Biofertilizantes: Caracterização química, qualidade sanitária e eficiência em diferentes concentrações na cultura da alface (Dissertação, Mestrado em Ciência do Solo, Universidade Federal do Paraná, Curitiba).

Wang, X., Chen, Y., Sui, P., Gao, W., Qin, F., Wu, X., \& Xiong, J. (2014). Efficiency and sustainability analysis of biogas and electricity production from a large-scale biogas project in China: An emergy evaluation based on LCA. Journal of Cleaner Prodution, 65, 234-245. https://doi.org/10.1016/j.jclepro.2013.09.001

\section{Copyrights}

Copyright for this article is retained by the author(s), with first publication rights granted to the journal.

This is an open-access article distributed under the terms and conditions of the Creative Commons Attribution license (http://creativecommons.org/licenses/by/4.0/). 